\title{
Follicle-Stimulating Hormone Receptor
}

National Cancer Institute

\section{Source}

National Cancer Institute. Follicle-Stimulating Hormone Receptor. NCI Thesaurus. Code C94809.

Follicle-stimulating hormone receptor (695 aa, $78 \mathrm{kDa}$ ) is encoded by the human FSHR gene. This protein is involved in the modulation of hormone binding and signaling and the mediation of both gonad development and gamete differentiation. 